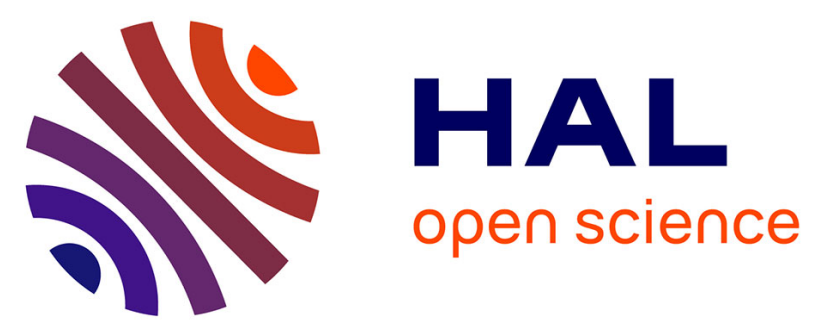

\title{
Development of ELISAs for detecting domoic acid, okadaic acid, and saxitoxin and their applicability for the detection of marine toxins in samples collected in Belgium
}

Michel Dubois, Luc Demoulin, Caroline Charlier, Philippe Delahaut, Katrina Campbell, Chris Elliott, Samuel Godefroy, Gurmit Singh

\section{To cite this version:}

Michel Dubois, Luc Demoulin, Caroline Charlier, Philippe Delahaut, Katrina Campbell, et al.. Development of ELISAs for detecting domoic acid, okadaic acid, and saxitoxin and their applicability for the detection of marine toxins in samples collected in Belgium. Food Additives and Contaminants, 2010, 27 (06), pp.859-868. 10.1080/19440041003662881 . hal-00593891

\section{HAL Id: hal-00593891 https://hal.science/hal-00593891}

Submitted on 18 May 2011

HAL is a multi-disciplinary open access archive for the deposit and dissemination of scientific research documents, whether they are published or not. The documents may come from teaching and research institutions in France or abroad, or from public or private research centers.
L'archive ouverte pluridisciplinaire HAL, est destinée au dépôt et à la diffusion de documents scientifiques de niveau recherche, publiés ou non, émanant des établissements d'enseignement et de recherche français ou étrangers, des laboratoires publics ou privés. 


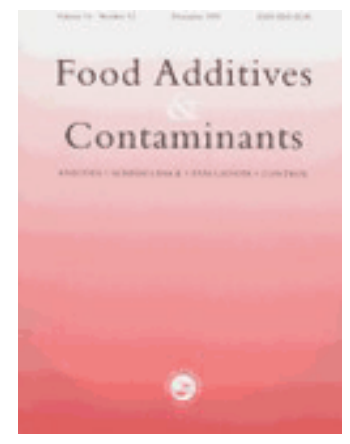

\section{Development of ELISAs for detecting domoic acid, okadaic acid, and saxitoxin and their applicability for the detection of marine toxins in samples collected in Belgium}

\begin{tabular}{|c|c|}
\hline Journal: & Food Additives and Contaminants \\
\hline Manuscript ID: & TFAC-2009-310.R1 \\
\hline Manuscript Type: & Original Research Paper \\
\hline $\begin{array}{r}\text { Date Submitted by the } \\
\text { Author: }\end{array}$ & $18-J a n-2010$ \\
\hline Complete List of Authors: & $\begin{array}{l}\text { Dubois, Michel; CER, SAH } \\
\text { Demoulin, Luc; CER, SAH } \\
\text { Charlier, Caroline; CER Groupe, santés animale et humaine } \\
\text { Delahaut, Philippe; CER, Hormonologie } \\
\text { Campbell, Katrina; Queen University } \\
\text { Elliott, Chris; Queens University, Belfast, School of Biological } \\
\text { Sciences } \\
\text { Godefroy, Samuel; Health Canada, Bureau of Chemical Safety } \\
\text { Singh, Gurmit; Health Canada, Bureau of Chemical Safety }\end{array}$ \\
\hline Methods/Techniques: & Immunoassays, In-house validation, Screening - ELISA \\
\hline Additives/Contaminants: & Phycotoxins \\
\hline Food Types: & Seafood \\
\hline
\end{tabular}

\section{SCHOLARONE" \\ Manuscripts}




\title{
Development of ELISAs for detecting domoic acid, okadaic acid, and saxitoxin and their applicability for the detection of marine toxins in samples collected in Belgium
}

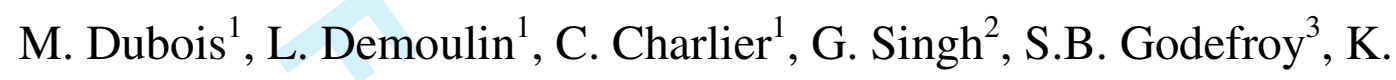 \\ Campbell $^{4}$, C.T. Elliott ${ }^{4}, \mathrm{Ph}$. Delahaut ${ }^{1}$. \\ ${ }^{1}$ CERgroupe, Departement Sante, Rue du Point du Jour 8, 6900 Marloie, Belgium. \\ ${ }^{2}$ Food Research Division, Health Canada, Ottawa, Ontario, Canada, K1A OL2 \\ ${ }^{3}$ Food Directorate-HPFB, Health Canada \\ ${ }^{4}$ Institute of Agri-Food and Land Use, Queen's University Belfast, Stranmillis Road, Belfast \\ BT9 5AG, UK
}




\begin{abstract}
Okadaic acid (OA), a diarrhetic shellfish poison (DSP), domoic acid (DA), an amnesic shellfish poison (ASP) and saxitoxin (SAX), a paralytic shellfish poison (PSP), are three of the best-known marine biotoxins. The mouse bioassay is the method most widely used to detect many of these toxins in shellfish samples, but animal welfare concerns have prompted researchers to seek alternative methods of detection. In this study, three direct competitive enzyme-linked immunosorbent assays (ELISAs), each based on antibodies raised in rabbits against a conjugate of the analyte of interest, were developed for marine biotoxin detection in mussel, oyster, and scallop. One assay was for okadaic acid, one for saxitoxin, and one for domoic acid (DA) usually detected and quantified by HPLC-UV. All three compounds and a number of related toxins were extracted quickly and simply from the shellfish matrices with a 9:1 mixture of ethanol and water prior to analysis. The detection capabilities (CC $\beta$ values) of the developed ELISAs were $150 \mathrm{ug} \mathrm{kg}^{-1}$ for okadaic acid, $50 \mathrm{ug} \mathrm{kg}^{-1}$ for domoic acid, and 5 $\mathrm{ug} \mathrm{kg}{ }^{-1}$ or less for saxitoxin. The assays proved satisfactory when used over a 4-month period for the analysis of 110 real samples collected in Belgium.
\end{abstract}

Keywords: enzyme immunoassay; domoic acid; okadaic acid; saxitoxin; validation. 


\section{Introduction}

Over the past two decades, the frequency, intensity, and geographic distribution of harmful algal blooms has increased, along with the number of toxic compounds found in the marine food chain. Different explanations for this trend have been given, such as increased scientific awareness of toxic algal species, increased utilisation of coastal waters for aquaculture, transfer of shellfish stocks from one area to another, cultural eutrophication due to domestic, industrial, and agricultural wastes, increased mobility of humic substances and trace metals from soil due to deforestation and/or acid rain, and unusual climate conditions (Hallegraeff et al. 1995).

Phycotoxins produced by algae pose a significant potential threat to human health. A variety of symptoms are reported to arise after consumption of contaminated shellfish, including stomach cramps, abdominal pain, diarrhoea, headaches, memory loss, paralysis, and in some extreme cases even death. In addition to the human health risk, the accumulation of these toxins in shellfish can also have severe consequences for the shellfish industry.

Monitoring the various toxin groups is therefore essential. Several families are responsible for poisonings, the symptoms and severity of which depend on the toxin family. Paralytic shellfish poisoning (PSP) is associated with a wide number of derivatives of saxitoxin (SAX). Diarrhetic shellfish poisoning (DSP) is caused by a group of polyether toxins including okadaic acid (OA), the dinophysistoxins (DTX-1, -2, -3...), pectenotoxin, and yessotoxin. Neurotoxic 
shellfish poisoning (NSP) is the result of exposure to a group of polyethers called brevetoxins, and amnesic shellfish poisoning (ASP) is caused by domoic $\operatorname{acid}(\mathrm{DA})$.

Because of the threat to human health, many countries (including European Union Member States) have enacted regulations on the maximum permitted levels of various phycotoxins. In the European Union, Regulation (EC) No 853/2004 lays down specific hygiene rules for food of animal origin. For live bivalve molluscs, this regulation stipulates that, in addition to meeting microbiological criteria and having organoleptic characteristics associated with freshness and viability, live bivalve molluscs must not contain marine biotoxins in total quantity measured in the whole body (or any edible part separately) exceeding the following limits: $800 \mathrm{ug} \mathrm{kg}^{-1}$ for the PSP toxins, $20 \mathrm{mg} \mathrm{kg} \mathrm{kg}^{-1}$ domoic acid equivalents for the ASP toxins, $160 \mathrm{ug} \mathrm{kg}^{-1}$ okadaic acid equivalents for okadaic acid, dinophysistoxins, and pectenotoxins together. For yessotoxins and azaspiracids, the maximum permissible level is $1 \mathrm{mg} \mathrm{kg}^{-1}$ yessotoxin equivalents and $160 \mathrm{ug} \mathrm{kg}^{-1}$ azaspiracid equivalents.

The method officially recognised by regulatory authorities for the detection of the aforementioned toxins is the mouse bioassay. Alternative methods can be used, provided they are no less effective and ensure the same level of public health protection. A series of instrumental methods (Hess et al. 2005; Diener et al. 2006; AOAC 2005), immunoassays (Botre et al. 2000; Garthwaite et al. 


\section{Materials and methods}

Reagents, chemicals, and apparatus.

Domoic acid, okadaic acid, saxitoxin, and other phycotoxin standards and certified reference materials (CRM-ASP-Mus-C, CRM-DSP-Mus-b) were purchased from the National Research Council of Canada's Institute for Marine Biosciences (Halifax, Canada).

Human serum albumin (HSA), bovine serum albumin (BSA), 1-ethyl-3-(3dimethylaminopropyl) carbodiimide, N-hydroxysuccinimide, and complete Freund's adjuvant were obtained from Sigma (St Louis, MO, USA). New Zealand female rabbits were used for immunisation. Nunc Maxisorp surface 96well polystyrene microtitre plates were purchased from Nunc (Roskilde, 
Denmark). All solvents were of LC or analytical reagent grade. Mussel, oyster, and scallop samples were obtained from local supermarkets.

A Multiskan EX Thermo Fisher Scientific microplate reader (Zellik, Belgium) was used to read the absorbance in the ELISA-plate wells at $450 \mathrm{~nm}$.

Preparation of immunogens.

Domoic acid and okadaic acid were conjugated with HSA by means of carbodiimide and N-hydroxysuccinimide. To $50 \mu \mathrm{L}$ dimethyl sulfoxide (DMSO) containing $1 \mathrm{mg}$ domoic acid or okadaic acid, $20 \mu \mathrm{L}$ 1-ethyl-3-(3dimethylaminopropyl) carbodiimide hydrochloride solution $\left(25 \mathrm{mg} \mathrm{mL}^{-1}\right.$ in DMSO) and $10 \mathrm{uL} \mathrm{N-hydroxysuccinimide} \mathrm{solution} \mathrm{(30} \mathrm{mg} \mathrm{mL}^{-1}$ in DMSO) were added. After stirring for $1.5 \mathrm{~h}$ at $25^{\circ} \mathrm{C}, 0.25 \mathrm{~mL}$ of HSA solution $\left(20 \mathrm{mg} \mathrm{mL}^{-1}\right.$ in $0.085 \mathrm{M}$ borate buffer containing $0.06 \mathrm{M} \mathrm{NaCl}, \mathrm{pH}$ 8.2) was added to the mixture. After incubation for $1.5 \mathrm{~h}$ at $25^{\circ} \mathrm{C}$, the reaction mixture was loaded onto a PD-10 column (Pharmacia Biotech, Uppsala, Sweden) equilibrated with phosphate buffered saline (PBS). After elution, the protein-containing portion $(3.5 \mathrm{~mL})$ was collected. The toxin-protein conjugates were then stored at $-30^{\circ} \mathrm{C}$ until used.

The saxitoxin immunogen was prepared according to Renz V and Terplan G (1988). Typically, BSA (2 mg) in sodium acetate buffer $\left(0.1 \mathrm{~mol} \mathrm{~L}^{-1}, \mathrm{pH} 4.4,0.5\right.$ $\mathrm{mL})$ was mixed with saxitoxin diacetate $(150 \mathrm{ug})$ in the presence of formaldehyde $(37 \% \mathrm{~W} / \mathrm{W}, 40 \mathrm{uL})$. The reaction was left to proceed at room 
temperature for $72 \mathrm{~h}$, then at $4^{\circ} \mathrm{C}$ for another $12 \mathrm{~h}$. The reaction mixture was dialysed against $1 \mathrm{mmol} \mathrm{L}^{-1}$ acetic acid solution for $6 \mathrm{~h}$, then against deionised water for $18 \mathrm{~h}$. After dialysis the SAX-BSA was precipitated overnight at $4^{\circ} \mathrm{C}$ with aluminium potassium sulfate $(10 \%, 800 \mathrm{uL})$ and $\mathrm{NaOH}\left(1 \mathrm{~mol} \mathrm{~L}^{-1}, 500\right.$ $\mathrm{uL})$. The resulting precipitate was washed six times with cold PBS, pH 7.2. Preparation of enzyme-labelled drugs.

The two phycotoxins (domoic acid and okadaic acid) were conjugated to horseradish peroxidase (HRP) enzyme label by the same method as for the immunogens.

Saxitoxin was coupled to HRP by the periodate reaction [16]; HRP (4 mg) was added to a sodium periodate solution $\left(0.1 \mathrm{~mol} \mathrm{~L}^{-1}, 0.2 \mathrm{~mL}\right)$ and the solution was gently mixed for $20 \mathrm{~min}$ at room temperature. The mixture was dialysed overnight at $4^{\circ} \mathrm{C}$ against sodium acetate buffer, $\mathrm{pH} 4.4$, and the $\mathrm{pH}$ of the final solution was adjusted with carbonate buffer $\left(0.2 \mathrm{~mol} \mathrm{~L}^{-1}, \mathrm{pH} 9.6,20 \mu \mathrm{L}\right)$. The activated enzyme was added to saxitoxin as an acetate salt (80 ug) in acetic acid $\left(0.1 \mathrm{~mol} \mathrm{~L}^{-1}, 250 \mathrm{uL}\right)$ and the $\mathrm{pH}$ was adjusted to 7.5 with sodium carbonate buffer (0.5 mol L'- $\left.{ }^{-1} \mathrm{pH} 9.6\right)$.

After $45 \mathrm{~min}$ at room temperature, $\mathrm{NaBH}_{4}\left(4 \mathrm{mg} \mathrm{mL} \mathrm{m}^{-1}, 0.1 \mathrm{~mL}\right)$ was added. The mixture was incubated for $15 \mathrm{~min}$ at $4^{\circ} \mathrm{C}$ and finally dialysed against PBS $(0.15$ mol L $\left.{ }^{-1}\right)$. The saxitoxin conjugate was stored at $-20^{\circ} \mathrm{C}$.

Immunisation of rabbits. 
Immunogen emulsions were injected subcutaneously into four sites on the animal. Rabbits were immunised every 28 days with 200 ug immunogen, and blood samples were taken from the marginal vein of the ear 10 days after each immunisation (from the third immunisation onward). Test bleeds were monitored every 28 days for the presence of antibodies. When titres stabilised, the rabbits were exsanguinated and the resulting antisera stored at $-20^{\circ} \mathrm{C}$.

Assessment of antibodies and enzyme conjugates.

All antibodies and enzyme conjugates were initially assessed by means of ELISA chequerboards to determine optimum working dilutions.

Specificity of antibodies.

Specificity means the ability of a method to distinguish between the analyte being measured and other substances. Sixty blank shellfish samples (20 mussel, 20 oyster, and 20 scallop samples) were analysed in blind duplicate.

The specificities of the three antibodies were assessed by determining the extent to which each one cross-reacted, in the ELISA, with analytes having a chemical structure similar to that used to raise the antibody. The degree of antibody specificity within the amnesic, diarrhetic, and paralytic poison families was estimated by means of the competitive ELISAs described in section 2.7. Crossreactivity was calculated by means of the formula:

$\underline{\text { ID } 50 \text { of compound used to raise antibody }}$ X 100 
ID 50 of the competing compound

\section{Competitive ELISA procedure.}

Ninety-six-well Nunc Maxisorp microtitre plates (Roskilde, Denmark) were coated beforehand with purified sheep antibody directed against rabbit IgG (CER, Marloie, Belgium). The wells were filled with $50 \mu \mathrm{L}$ working standard prepared in assay buffer (the standard was chosen according to the residue to be detected), $50 \mu \mathrm{L}$ diluted sample, or $50 \mu \mathrm{L}$ assay buffer (Bo). The ELISA buffer composition was as follows: $0.15 \mathrm{M} \mathrm{NaCl}, 0.056 \mathrm{M} \mathrm{Na}_{2} \mathrm{HPO}_{4} .2 \mathrm{H}_{2} \mathrm{O}, 0.009 \mathrm{M}$ $\mathrm{NaH}_{2} \mathrm{PO}_{4} .2 \quad \mathrm{H}_{2} \mathrm{O}, \quad 0.2 \%$ gelatin, $0.05 \%$ Tween $20,0.01 \%$-anilino-1naphthalenesulfonic acid ammonium salt, and $0.0028 \mathrm{M}$ ascorbic acid. Two additional wells were filled with $150 \mathrm{uL}$ assay buffer and were dedicated to nonspecific binding (NSB). The peroxidase conjugate and the antiserum (diluted to its optimal concentration in assay buffer), were then dispensed into the wells (the conjugate and antiserum were chosen according to the residue to be detected). The diluted antibody was added to each well except for the two wells corresponding to NSB. The microtitre plate was incubated at $4^{\circ} \mathrm{C}$ for 2 hours (OA and DA ELISAs) or overnight (SAX ELISA).

The wells were then emptied and washed three times with washing buffer $(0.15$ $\mathrm{M} \mathrm{NaCl}, 0.05 \%$ Tween 20$)$. A $150-\mu \mathrm{L}$ aliquot of chromogen mixture $[(3,3 ', 5$, 5'-tetramethylbenzidine) (TMB) and enzyme substrate $\left.\mathrm{H}_{2} \mathrm{O}_{2} ; \mathrm{v} / \mathrm{v}\right)$ ] was added to each well. The enzyme reaction was stopped by addition of $6 \mathrm{M}$ sulfuric acid 
$(50 \mu \mathrm{L})$. The absorbance of the solution at $450 \mathrm{~nm}$ was read within $30 \mathrm{~min}$. The average optical density $\left(\mathrm{OD}_{450}\right)$ of the Bo wells, containing all constituents except the phycotoxin competitor, was taken as $100 \%$ activity. Percent inhibition was calculated as:

$$
\frac{\left(\mathrm{OD}_{450 \text { test }}-\mathrm{OD}_{450 \mathrm{NSB}}\right)}{\left(\mathrm{OD}_{450 \mathrm{Bo}}-\mathrm{OD}_{450 \mathrm{NSB}}\right)}
$$

\section{Sample extraction.}

Tissues were homogenised in a blender ( $3 \mathrm{~min}$ ), which was cleaned and rinsed with methanol and distilled water after each sample. One gram of tissue homogenate was vortexed for $1 \mathrm{~min}$ in the presence of $5 \mathrm{ml}$ ethanol-water (9/1). After centrifugation (10 $\mathrm{min}$ at $3000 \mathrm{~g}$ ), the supernatant was decanted and the tissues extracted again with a new aliquot $(3 \mathrm{~mL})$ of the same ethanol-water mixture. The final volume of the extract was made up to $10.0 \mathrm{~mL}$ and filtered through a 25-mm filter with a 0.45-um-pore-size nylon filter membrane (Whatman). The extract was stored at $4^{\circ} \mathrm{C}$ and diluted in ELISA buffer prior to ELISA-based detection and quantification.

\section{Determination of detection capability.}

The detection capability of an analytical procedure is defined in Decision 2002/657/EC as the smallest amount of a substance that can be detected, identified, and/or quantified in a sample with an error probability of $\beta$. 
Twenty blanks of known non-contaminated mussels and twenty blank mussel samples fortified at $150 \mathrm{ug} \mathrm{kg}^{-1}$ with domoic acid, $50 \mathrm{ug} \mathrm{kg}^{-1}$ with okadaic acid, or $2 \mathrm{ug} \mathrm{kg}^{-1}$ with saxitoxin, were prepared "blind to the analyst" and analysed in duplicate. The ELISA plates were then processed as previously described.

The detection capability CC $\beta$ (cut-off) was calculated as the concentration at which less than $5 \%$ of false-compliant results remained. If 19 samples among 20 fortified samples were declared positive, then $\mathrm{CC} \beta=$ level of fortification. If 18 or less of the fortified samples were declared positive, then $\mathrm{CC} \beta>$ level of fortification. If all the fortified samples were declared positive then $\mathrm{CC} \beta<$ level of fortification. The method was repeated by gradually increasing the level of fortification until CC $\beta$ was determined. This validation procedure was repeated for the other two matrices of interest (oyster and scallop).

\section{Results and Discussion}

ELISA assays for the various toxin classes were developed. Emphasis was placed on keeping the methods and all reagents as similar as possible in the three assay procedures.

The performance characteristics sensitivity, specificity, and detection capability $(\mathrm{CC} \beta)$ of the three ELISAs in screening for domoic acid, okadaic acid, and saxitoxin in shellfish were determined in order to validate the ELISAs and to 
test the possibility of using them to screen shellfish for low levels of phycotoxins. The three methods were validated according to the criteria of European Decision 2002/657/EC (Commission 2002) for a screening method.

Antibody sensitivity.

All three of the shellfish toxin immunogens resulted in the production of antibodies. Sera exhibiting antibody titres were assessed for their sensitivity and specificity. Each rabbit serum was tested with the corresponding peroxidase conjugate.

The assay sensitivity was calculated as $50 \%$ inhibition of deviation (ID 50), the concentration of shellfish toxin necessary to cause $50 \%$ antibody binding. The competitive ELISA format described in previously section was used to determine the assay sensitivity. A set of shellfish toxin standards (in the range of 0.005-10 $\mathrm{ng} \mathrm{mL}^{-1}$ ) was used. The average optical density of zero standard wells (Bo) represents $100 \%$ activity and the remaining standards were normalised with respect to the optical density of Bo.

Several parameters were tested to determine the optimal conditions for each ELISA, notably incubation temperature and incubation time. These parameters were evaluated by comparing the antibody sensitivity (ID 50) while taking into account the practical requirements of potential users. First, the results obtained at two incubation temperatures, 4 and $37^{\circ} \mathrm{C}$ were compared. The sensitivity was substantially better (no data presented) when the incubation temperature was 
$4^{\circ} \mathrm{C}$. Second, the results obtained at two incubation times, overnight or $2 \mathrm{~h}$, were compared. The best incubation times were 2 hours for domoic acid and okadaic acid and overnight for saxitoxin. The best incubation temperature was $4^{\circ} \mathrm{C}$ for the three ELISAs. Under these conditions, the respective mid-point of the DA, OA, and SAX calibration curve (ID 50) obtained were 1.8, 1.3 and $0.04 \mathrm{ng} \mathrm{ml}^{-1}$. Representative standard curves for domoic acid, okadaic acid and saxitoxin, obtained with the optimised ELISA are shown respectively in Figures 1. It appears that inhibition of binding of domoic acid was linear in the range $0.1-$ $10 \mathrm{ng} \mathrm{mL}^{-1}$. It was also reproducible in this range, its standard deviation being no more than $\pm 5 \%$.

Antibody specificity.

The cross-reactivities in assay buffer of the anti-OA, anti-DA, and anti-SAX antibodies are given in Table 1. The ELISAs were performed with increasing amounts of competitor. When no ID 50 could be determined within the tested concentration range because the binding calculated in percent was superior to $50 \%$ for the highest concentration, the ID used in the cross-reactivity formula was the ID observed at that concentration and the cross-reactivity was recorded as inferior to the result of the calculation.

The anti-DA antibody showed $100 \%$ cross-reactivity with domoic acid and no significant cross-reactivity with any other shellfish toxin. As the total domoic acid concentration in the certified reference material (CRM) MUS-1 was 
accurately determined (Table 2), it would appear that the antiserum cross-reacts well with all major isomers of domoic acid and that this ELISA provides a measurement of total domoic acid (the summed concentrations of the various domoic acid isomers).

The anti-OA antibody was tested for cross-reactivity towards two OA analogues of the same toxin family: the dinophysistoxins DTX-1 and DTX-2. It showed $78 \%$ cross-reactivity towards DTX-1 and $2.6 \%$ cross-reactivity towards DTX-2, as compared to OA. An ELISA developed for DSP detection should detect okadaic acid and the dinophysistoxins equally, but no such ELISA is available. Detection of DTX-3 requires an extra base hydrolysis step in the extract preparation procedure to remove the acyl group and convert the toxin to DTX-1. Commercially available ELISAs for this group include the DSP-Check ${ }^{\circledR}$ ELISA test kit from UBE Industries, Tokyo, Japan and the Rougier Bio-Tech ${ }^{\circledR}$ ELISA test kit. The former is used worldwide to screen for OA and DTX-1 at a claimed detection limit of $20 \mathrm{ng} \mathrm{g}^{-1}$. The latter exploits a monoclonal anti-OA antibody and an anti-idiotypic antibody that competes with OA for binding sites on the anti-OA antibody. This antibody exhibits a much higher sensitivity (10-20 fold) for OA than for either DTX-1 or DTX-2, whereas DTX-3 does not cross-react at all.

The anti-SAX antiserum showed $100 \%$ cross-reactivity with saxitoxin, $26.2 \%$ with GTX 5 (gonyautoxin-5), 19.2\% with decarbamoyl saxitoxin, and 5.6\% with GTX 2/3 (gonyautoxin-2 and gonyautoxin-3). It showed very low cross- 
reactivity with neo-saxitoxin (1.4\%). It is a well-recognised problem that all PSP antibodies fail to recognise all members of the toxin family and thereby underestimate the total toxin content. This notably concerns the PSPs, as antiSAX antibodies show poor cross-reactivity with neo-saxitoxin and vice versa (Usleber et al. 1994; Huang et al. 1996). The commercial ELISA test kits have only been developed for SAX. However, they are not totally specific for SAX and some reactions are induced to decarbamoyl-SAX (dcSAX) and neoSAX. Usleber et al. (1997) have concluded that ELISA results correlated well with mouse bioassay results when analysing scallops. However, Kasuga et al. (1996) have concluded that the mouse assay can not be replaced with ELISA for the purpose of screening inshore shellfish samples, as unpredictable cross-reactions have occurred, as well as underestimations of toxicity of some naturally contaminated shellfish samples, harvested in the sea near Japan. The predominance of GTX's and the lack of SAX in shellfish samples resulted in the underestimation of toxin content by the ELISA kit in comparison with the PSP mouse bioassay. The major advantages of ELISA are simplicity, and rapidity of the test procedure, and a higher sensitivity compared with other methods. However, quantitative agreement between ELISA and mouse bioassay depends on the antibody specificity and on the toxin profile of the shellfish. Thus both over- and under-estimation of total toxicity may occur.

In order to avoid the poor cross-reactivity of saxitoxin antibodies with neosaxitoxin and vice versa, one could use two or more ELISAs based on antibody 
recognition of different members of the same toxin family. Chu et al. (1996) has demonstrated the feasibility of this approach, finding a very high correlation between the results mouse PSP bioassays and those obtained by summing the results of SAX and neo-SAX ELISAs. The ease and speed of ELISAs makes it relatively simple to conduct several ELISAs in parallel. The use of two ELISAs to cover a particular toxin group requires only a little additional work.

Another approach [9] is to develop a competitive enzyme immunoassay based on a gonyautoxin 2/3 (GNTX2/3)-specific monoclonal antibody and a saxitoxinhorse radish peroxidase conjugate. GNTX2/3, dc-GNTX2/3, C1/2, GNTX1/4, STX and neoSTX were detectable at concentrations lower than the regulatory limit of $80 \mathrm{ug} / 100 \mathrm{~g}$ of shellfish tissue.

As far as screening purposes are concerned, ELISAs offer major advantages compared with the mouse bioassay, which is criticized in Europe because of animal welfare. Considering the presence of cross-reactions with lower binding specificity and the potential lack of response to other toxins than saxitoxin within the PSP group, the practical application of these assays will probably remain limited, unless acceptable performance characteristics can be demonstrated in formal collaborative studies according to AOAC International or ISO accepted procedures.

Detection capability. 
The smallest content of the substance that may be detected by each ELISA was assessed by determining the detection capability (CC $\beta$ ) of the assay for the shellfish toxin to be detected. To evaluate the performance of our ELISAs, three matrices were chosen: mussel, oyster, and scallop. For each matrix, known negative samples were unfortified (blank) and fortified with phycotoxins at various concentrations, extracted, and analysed by means of the optimised ELISAs. The detection capability was determined for each toxin in each matrix. In the mussel, oyster and scallop matrix, the respective $\mathrm{CC} \beta$ values for DA, OA, were 150 and $50 \mathrm{ug} \mathrm{kg}^{-1}$. For the saxitoxin, the respective $\mathrm{CC} \beta$ values for mussel, oyster and scallop matrix were 1,2 and $5 \mathrm{ug} \mathrm{kg}^{-1}$.

The results presented in Figures 2, 3,4 demonstrate that the blank and spiked oyster samples met the CC $\beta$ criterion: all blank oyster samples gave a response below the $\mathrm{CC} \beta$, while at least 19 out of 20 spiked samples gave a signal above the $\mathrm{CC} \beta$ and were thus classified as suspect $(\beta=5 \%)$.

In practice, the means of the absorbance values obtained for each sample were divided by the absorbance of the zero standard (Bo) and multiplied by 100 . For each group of 20 samples, the mean ratio $\mathrm{B} / \mathrm{Bo}(\%)+/-2$ standard deviations was calculated (Figures 2, 3, 4). These data show that there was no B/Bo (\%) range overlap between the blank and spiked samples.

For example, in the case of domoic acid in oyster (Figure 2), a 91\% threshold is the lower limit of the blank range and $89 \%$ is the upper limit of the spiked 
sample range (cut-off). In the routine application of such a qualitative method a sample was considered suspect if the binding percentage was below or equal the cut-off. Thus the assays developed could be used in highly reliable manner to differentiate between samples free from domoic acid or okadaic acid or saxitoxin from those with these phycotoxins above the $\mathrm{CC} \beta$ values.

\section{Extraction, recovery.}

The present method has the advantage that a single solvent extraction system adequately extracts the ASP, DSP, and PSP toxins. Ethanol is a preferred solvent because of its low toxicity and volatility. In most assays it causes lesser matrix effects than methanol. The extraction efficiency was evaluated by comparing the calibration curves constructed before and after extraction of blank matrices spiked with a known amount of phycotoxin. An extraction efficiency above 90\% was obtained for domoic acid, okadaic acid, and saxitoxin, indicating that the proposed extraction is suitable for use in screening for both aqueous and lipophilic toxins. Matrix effects of alcohol extracts in the ELISA were eliminated by dilution of the shellfish extract with PBS until the standard curves obtained for toxins dissolved in ELISA-buffer-diluted shellfish extract coincided with those obtained for toxins dissolved in ELISA buffer.

Toxin recovery was determined by spiking shellfish samples with the target toxin and also by analysing the following CRMs: CRM-ASP-Mus-C and CRM- 
DSP-Mus-b. CRM-ASP-Mus-C is a mussel tissue homogenate containing $41 \pm 2$ $\mathrm{mg} \mathrm{kg}^{-1}$ domoic acid, as well as several related compounds (isomers). The sum of the concentration of domoic acid and C5'-epidomoic acid is certified at $44 \pm 3$ mg kg ${ }^{-1}$. In CRM-DSP-Mus-b, a CRM for okadaic acid and DTX-1, the toxin levels are $10.1 \mathrm{mg} \mathrm{kg}^{-1}$ for okadaic acid and $1.3 \mathrm{mg} \mathrm{kg}^{-1}$ for DTX-1.

The results for recovery of DA, OA and saxitoxin added to the extracts of mussels, oysters and scallop are shown in table 2 . DA was detected in CRMASP-Mus-C with a mean recovery of $105 \%$ and coefficient of variation of $9 \%$.

OA was detected in CRM-DSP-Mus-b with a mean recovery of $109 \%$ and coefficient of variation of $11 \%$. Saxitoxin added to the mussel was detected with a mean recovery of $112 \%$ and coefficient of variation of $8 \%$.

Analysis of real samples from the Belgian market.

One hundred and ten samples (42 mussels, 61 scallops and 7 oysters) were collected in Belgium between October 2007 and January 2008. One hundred and three of these samples were collected by the Belgian Veterinary Inspectors for Public Health and seven by scientific personnel from different shops located in the south of Belgium (Walloon region). Samples were frozen and kept at approximately $-20^{\circ} \mathrm{C}$ until analysis. The 110 real samples were analysed with the three validated ELISAs developed for screening shellfish for domoic acid, okadaic acid, and saxitoxin. The analyses were performed on 11 different days 
over a period exceeding four months. Over this period, the methods showed good robustness. QC samples were analysed to check the performance of the assay. The results for negative QC samples and for positive QC samples spiked at the CC $\beta$ concentration were very satisfactory. Reagent blanks were always found compliant and the spiked reagent blanks were always determined as suspect. This confirms that the detection capability set during the initial validation was an acceptable threshold value.

Table $\underline{3}$ gives an overview of the contaminated samples. It was concluded that saxitoxin residues were present in one sample (mussel) at the concentration of 2 ug $\mathrm{kg}^{-1}$ and okadaic acid in one sample (mussel) at the CC $\beta$ concentration. Domoic acid was detected and quantified in 9 samples (concentration above the $\mathrm{CC} \beta)$. The incidence of domoic-acid-contaminated samples was $0 \%$ for mussel, $0 \%$ for oyster, and $15 \%$ for scallop. The domoic acid content was above the 20 $\mathrm{mg} \mathrm{kg}^{-1}$ limit (the EU-adopted maximum level) in 5 samples (8\%).

Since the present validated ELISAs for domoic acid, okadaic acid, and saxitoxin in shellfish are screening methods, suspect samples need to be confirmed by mass spectrometry. The contaminated samples were analysed by LC-MS/MS to confirm their contaminated status and to avoid overestimation due to interference. Analysis was done on a Quattro Premier (Waters) mass spectrometer in the ESI mode, using traces 312>266 and 312>161 for quantification and confirmation of domoic acid (Holland et al. 2003) and traces $804>255$ and 804>113 for quantification and confirmation of okadaic acid (Fux 
et al. 2007). These analyses confirmed the contaminant identities and concentrations determined by the ELISAs.

In addition, the ELISAs applied to mussel, oyster, and scallop samples successfully detected domoic acid and okadaic acid when they were shown to be present by LC-MS/MS. Hence, the occurrence of false negatives in the ELISAs for domoic acid and okadaic acid appears unlikely.

\section{Conclusions}

This work has led to the development of three quick, sensitive ELISAs for the detection of domoic acid, okadaic acid, and saxitoxin respectively in shellfish. The proposed technique requires little expensive apparatus or equipment. A major advantage of ELISAs over other methods is the ability to process relatively large numbers of samples over a short lapse of time. A single technician can prepare and extract up to 20 samples in approximately 4 hours. More rapid analyses of commercial shellfish samples would reduce the time the product must be held in storage and allow the prompt issue of the official documentation on shellfish toxin content required by some export markets. The reported methods have been validated according to the criteria laid down by the EU in Commission Decision 2002/657/EC and were used for more than 4 months for the analysis of the 110 real samples collected in Belgium. The domoic acid content was above the $20 \mathrm{mg} \mathrm{kg}^{-1}$ limit (EU-adopted maximum level) in 5 scallop samples (8\%). 


\section{Acknowledgements}

This work was funded by the SPF-Santé Publique, project Alteval 1 (RT 06/5).

We also thank the FAVV (Dr. Van Den Brande) for the collection of field samples. 


\section{References}

1) AOAC Official Method 2005.06, 2005. Paralytic Shellfish Poisoning Toxins in Shellfish. Prechromatograhic Oxidation and Liquid Chromatography with Fluorescence Detection. J AOAC Int. 88: 1714.

2) F. Botre, F. Mazzei 2000. Inhibition enzymatic biosensors: an alternative to global toxicity bioassays for the rapid determination of phycotoxins. Int. J. Environment and Pollution 13(1-6): 173-189.

3) F.S. Chu, K.H. Hsu, X. Huang, R. Barrett, C. Allison 1996. Screening of paralytic shellfish poisoning toxins in naturally occurring samples with three different direct competitive enzyme-linked immunosorbent assays. J Agric. Food Chem. 44: 4034-4047.

4) Commission Decision 2002/657/EC of 12 August 2002 implementing Council Directive 96/23/EC concerning the performance of analytical methods and the interpretation of results. Official Journal L 221, 17/18/2002 pp. 0008-0036.

5) M. Diener, K.Erler, S. Hiller, B. Christian, B. Luckas 2006. Determination of Paralytic Shellfish Poisoning (PSP) toxins in dietary supplements by application of a new HPLC/FD method. Eur Food Res Technol 224 :147151. 
6) E. S. Fonfrıa, N. Vilarino, K. Campbell, C.T. Elliott, S. A. Haughey, B. Ben-Gigirey, J. M. Vieites, K. Kawatsu, and L. M. Botana 2007. PSP detection by SPR-based biosensors in shellfish matrixes. Analytical Chemistry. Paralytic Shellfish Poisoning Detection by Surface Plasmon Resonance-Based Biosensors in Shellfish Matrixes. Analytical Chemistry 79: 6303-6311.

7) E. Fux, D. McMillan, R. Bire, P. Hess 2007. Development of an ultraperformance liquid chromatography-mass spectrometry method for the detection of lipophilic marine toxins. Journal of Chromatography A, 1157: 273-280.

8) I. Garthwaite, K. M. Ross, et al. 1998. Polyclonal antibodies to domoic acid, and their use in immunoassays for domoic acid in sea water and shellfish. Nat Toxins 6(3-4): 93-104.

9) I. Garthwaite, K. M. Ross, et al. 2001. Integrated enzyme-linked immunosorbent assay screening system for amnesic, neurotoxic, diarrhetic, and paralytic shellfish poisoning toxins found in New Zealand. J AOAC Int 84(5): 1643-8.

10) G.M. Hallegraeff, D.M. Anderson, A.D. Cembella 1995. Manual on harmful Marine microalgae. IOC Manuals and Guides 33: 1-551.

11) P. Hess, S. Morris, LA Stobo, NA Brown, JDG McEvoy, G. Kennedy, S. Gallacher 2005. LC-UV and LC-MS methods for the determination of domoic acid. Trends Anal Chem 24: 358-367. 
12) P.T. Holland, P. McNabb, A.I. Selwood, and T. Neil 2003. Amnesic Shellfish Poisoning Toxins in Shellfish: estimation of uncertainty of measurement for liquid chromatography/tandem mass spectrometry method. Journal of AOAC International, Vol. 86, No. 5: 1095-1100.

13) X. Huang, K.H. Hsu, F.S. Chu 1996. Direct Competitive Enzyme-Linked Immunosorbent Assay for Saxitoxin and Neosaxitoxin. J Agric. Food Chem. 44: 1029-35.

14) F. Kasuga, Y. HaraKudo, K. Machii 1996. Evaluation of Enzyme-Linked Immunosorbent Assay (ELISA) Kit for Paralytic Shellfish Poisoning Toxins. J Food Hyg. Soc. Japan 37(6): 407-410.

15) H. Kawatsu, Y. Hamano, et al. 2000. Determination of domoic acid in Japanese mussels by enzyme immunoassay. J AOAC Int 83(6): 1384-6.

16) K. Kawatsu, Y. Hamano, et al. 2002. Development and application of an enzyme immunoassay based on a monoclonal antibody against gonyautoxin components of paralytic shellfish poisoning toxins. J Food Prot. 65(8): 1304-8.

17) N.M. Llamas, L. Stewart; T.L. Fodey, C.T. Elliott 2007. Development of a novel immunobiosensor method for the rapid detection of okadaic acid contamination in shellfish extracts. Analytical and Bioanalytical Chemistry 389: $581-587$.

18) S. L. Morton and D. R. Tindall 1996. Determination of okadaic acid content of dinoflagellate cells: a comparison of the HPLC-fluorescent 
method and two monoclonal antibody ELISA test kits. Toxicon 34(8): 94754.

19) M. Osada, L. J. Marks, et al. 1995. Determination of domoic acid by two different versions of a competitive enzyme-linked immunosorbent assay (ELISA). Bull Environ Contam Toxicol 54(6): 797-804.

20) V. Renz, G. Terplan 1988. Detection of saxitoxin by an indirect competitive ELISA. Archiv fûr Lebensmittelhygiene 39(2): 30-33.

21) D.S. Smith, and D. D. Kitts 1994. A competitive enzyme-linked immunoassay for domoic acid determination in human body fluids. Food Chem Toxicol 32(12): 1147-54.

22) D. S. K. Smith, D.D. Kitts 1995. Enzyme Immunoassay for the determination of domoic acid in mussel extracts. J Agric. Food Chem. 43: $367-371$.

23) I. Traynor, L. Plumpton, T.L. Fodey, C. Higgins, C.T. Elliott 2006. Immunobiosensor detection of domoic acid as a screening test in bivalve mollusks: Comparison with LC based analysis. J AOAC. 89: 868-872.

24) E. Usleber, E. Schneider, G. Terplan 1991. Direct enzyme immunoassay in microtitration plate and test strip format for the detection of saxitoxin in shellfish. Lett Appl Microbio 13: 275-277.

25) E. Usleber, R. Dietrich, E.P. Martlbauer, G. Terplan 1994. Effect of heterologous paralytic shellfish poisoning toxin-enzyme conjugates on the 
cross-reactivity of a saxitoxin enzyme immunoassay. Lett. Appl. Microbiol 18: 337-339.

26) E. Usleber, M. Donald, M. Straka 1997. Comparison of enzyme immunoassay and mouse bioassay for determining paralytic shellfish poisoning toxins in shellfish. Food Add. Contam. 14(2): 193-198.

27) P. Vale and M. A. Sampayo 1999. Comparaison between HPLC and a commercial immunoassay kit for detection of okadaic acid and esters in Portuguese bivalves. Toxicon 37(11): 1565-77. 
Table 1: Cross-reactivities of polyclonal antibodies raised against domoic acid (DA), okadaic acid (OA), and saxitoxin (SAX) towards various marine toxins.

\begin{tabular}{|l|c|c|c|}
\cline { 2 - 4 } \multicolumn{1}{c|}{} & \multicolumn{3}{c|}{ Cross-reactivity (\%) } \\
\hline \multicolumn{1}{c|}{ Marine toxin } & DA & OA & SAX \\
\hline Domoic acid & 100 & $<0.1$ & $<0.1$ \\
\hline Okadaic acid & $<0.1$ & 100 & $<0.1$ \\
\hline Dinophysistoxin DTX-1 & $<0.1$ & 78 & $<0.1$ \\
\hline Dinophysistoxin DTX-2 & $<0.1$ & 2.6 & $<0.1$ \\
\hline Saxitoxin & $<0.1$ & $<0.1$ & 100 \\
\hline Decarbamoyl saxitoxin & $<0.1$ & $<0.1$ & 19.2 \\
\hline Gonyautoxins GTX 2/3 & $<0.1$ & $<0.1$ & 5.6 \\
\hline GTX 5 & $<0.1$ & $<0.1$ & 26.2 \\
\hline Decarbamoyl GTX 2/3 & $<0.1$ & $<0.1$ & 0.2 \\
\hline Neosaxitoxin & $<0.1$ & $<0.1$ & 1.4 \\
\hline Decarbamoyl neosaxitoxin & $<0.1$ & $<0.1$ & 0.5 \\
\hline Gonyautoxins GTX 1/4 & $<0.1$ & $<0.1$ & $<0.1$ \\
\hline C1 and C2 & $<0.1$ & $<0.1$ & 0.2 \\
\hline B $_{1}$ and $\mathrm{B}_{2}$ & $<0.1$ & $<0.1$ & $<0.1$ \\
\hline
\end{tabular}


Table 2: Recovery or trueness, coefficient of variation (CV) obtained in analyses of domoic acid (DA), okadaic acid (OA), and saxitoxin (SAX) in mussel, oyster, and scallop.

\begin{tabular}{|c|c|c|c|}
\hline $\begin{array}{l}\text { Spiked sample } \\
\text { or CRM }\end{array}$ & $\begin{array}{c}\text { Mussel } \\
\text { Recovery or Trueness } \\
(C V)\end{array}$ & $\begin{array}{c}\text { Oyster } \\
\text { Recovery or Trueness } \\
(C V)\end{array}$ & $\begin{array}{c}\text { Scallop } \\
\text { Recovery or Trueness } \\
(C V)\end{array}$ \\
\hline $\begin{array}{l}\text { DA spiked sample } \\
\quad\left(5 \mathrm{mg} \mathrm{kg}^{-1}\right)\end{array}$ & $\begin{array}{l}95 \% \\
(11)\end{array}$ & $\begin{array}{c}108 \% \\
(13)\end{array}$ & $\begin{array}{l}96 \% \\
(10)\end{array}$ \\
\hline $\begin{array}{l}\text { OA spiked sample } \\
\left(0.16 \mathrm{mg} \mathrm{kg}^{-1}\right)\end{array}$ & $\begin{array}{c}86 \% \\
(7)\end{array}$ & $\begin{array}{c}85 \% \\
(6)\end{array}$ & $\begin{array}{c}101 \% \\
(9)\end{array}$ \\
\hline $\begin{array}{l}\text { SAX spiked sample } \\
\left(0.005 \mathrm{mg} \mathrm{kg}^{-1}\right)\end{array}$ & $\begin{array}{c}112 \% \\
(8)\end{array}$ & $\begin{array}{c}116 \% \\
(10)\end{array}$ & $\begin{array}{l}106 \% \\
(11)\end{array}$ \\
\hline $\begin{array}{l}\text { CRM-ASP-Mus-C } \\
\left(44 \mathrm{mg} \mathrm{kg}^{-1}\right)\end{array}$ & $\frac{105 \%}{(9)}$ & - & - \\
\hline $\begin{array}{l}\text { CRM-DSP-Mus-b } \\
\left(11.4 \mathrm{mg} \mathrm{kg}^{-1}\right)\end{array}$ & $\frac{109 \%}{(11)}$ & - & - \\
\hline
\end{tabular}


Table 3: Domoic acid (DA), okadaic acid (OA), and saxitoxin (SAX) contamination in real samples of mussel, oyster, and scallop collected in Belgium.

\begin{tabular}{|l|c|c|c|}
\hline & $\begin{array}{c}\text { Domoic acid } \\
\text { ELISA }\end{array}$ & $\begin{array}{c}\text { Okadaic acid } \\
\text { ELISA }\end{array}$ & $\begin{array}{c}\text { Saxitoxin } \\
\text { ELISA }\end{array}$ \\
\hline $\begin{array}{l}\text { Number of samples (mussel, oyster, scallop) } \\
\text { analysed by each ELISA }\end{array}$ & 110 & 110 & 110 \\
\hline Number of mussel samples analysed & 42 & 42 & 42 \\
Number of mussel (concentration > CC $\beta$ ) & 0 & 1 & 1 \\
Number of mussel (concentration > MRL) & 0 & 0 & 0 \\
\hline Number of oyster samples analysed & 7 & 7 & 7 \\
Number of oyster (concentration > CC $\beta$ ) & 0 & 0 & 0 \\
\hline Number of scallop samples analysed & 61 & 61 & 61 \\
Number of scallop (concentration > CC $\beta$ ) & 9 & 0 & 0 \\
Number of scallop (concentration > MRL) & 5 & 0 & 0 \\
Proportion of scallop (concentration > MRL) & $8 \%$ & $0 \%$ & $0 \%$ \\
\hline
\end{tabular}


Figure 1: ELISA standard curves for domoic acid (DA), okadaic acid (OA) and saxitoxin (SAX) in assay buffer spiked respectively with DA, OA and SAX standards. Calibration curve parameters: anti-DA antibody dilution, 1/16,000; DA conjugate dilution, 1/4,000; incubation time, 2 hours; incubation temperature, $4{ }^{\circ} \mathrm{C}$; anti-OA antibody dilution, 1/32,000; OA conjugate dilution, 1/32,000; incubation time, 2 hours; incubation temperature, $4^{\circ} \mathrm{C}$; anti-SAX antibody dilution, 1/32,000; SAX conjugate dilution, 1/1000; incubation time, overnight; incubation temperature, $4^{\circ} \mathrm{C}$. Under these conditions, the respective mid-point of the DA, OA, and SAX calibration curve (ID 50) obtained were 1.8 , 1.3 and $0.04 \mathrm{ng} \mathrm{ml}^{-1}$.

Figure 2: Detection capability $(\mathrm{CC} \beta)$ : graphic representation of 20 blanks (mean +/- 2 standard deviation) and 20 oyster samples spiked at $150 \mathrm{ug} \mathrm{kg}{ }^{-1}$ domoic acid (mean +/- 2 standard deviation).

Figure 3: Detection capability $(\mathrm{CC} \beta)$ : graphic representation of 20 blanks (mean +/- 2 standard deviation) and 20 oyster samples spiked at $50 \mathrm{ug} \mathrm{kg}^{-1}$ okadaic acid (mean +/- 2 standard deviation).

Figure 4: Detection capability $(\mathrm{CC} \beta)$ : graphic representation of 20 blanks (mean +/- 2 standard deviation) and 20 oyster samples spiked at $2 \mathrm{ug} \mathrm{kg}^{-1}$ saxitoxin(mean $+/-2$ standard deviation). 


\section{Figure 1:}

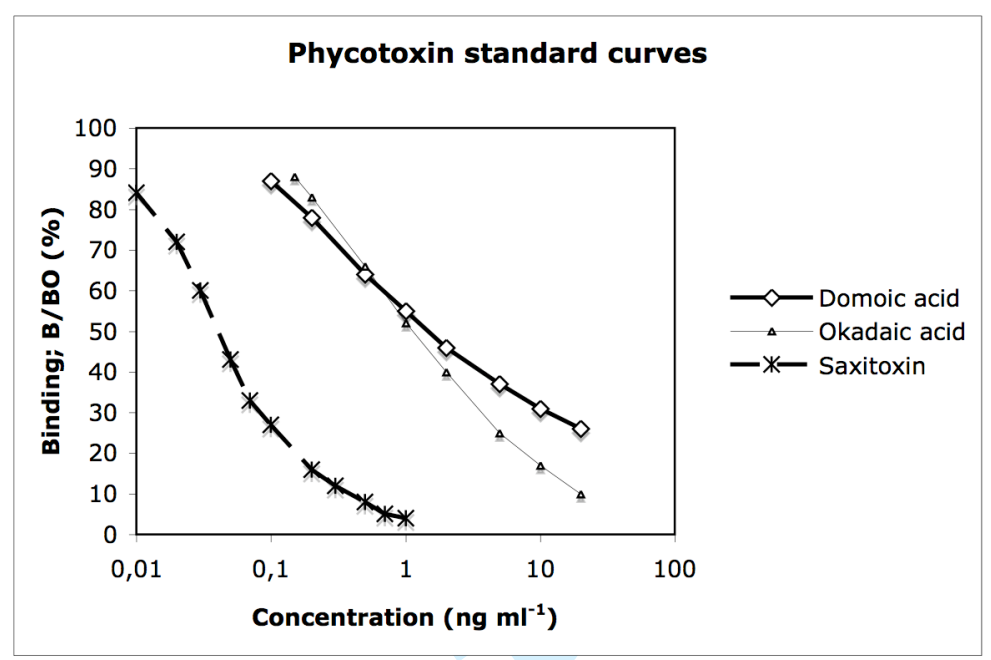


Figure 2:

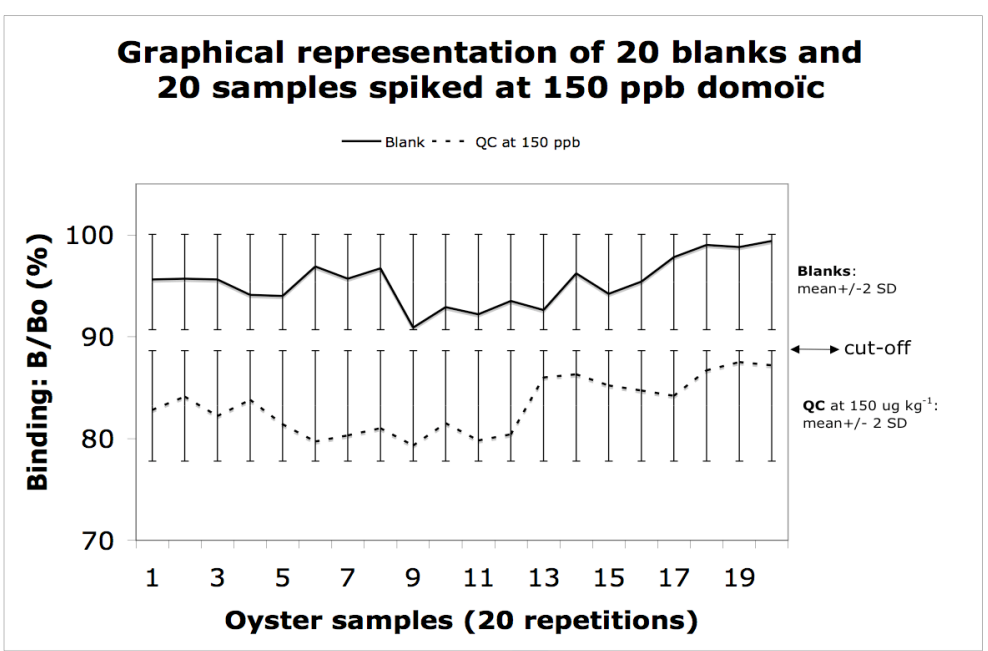




\section{Figure 3:}

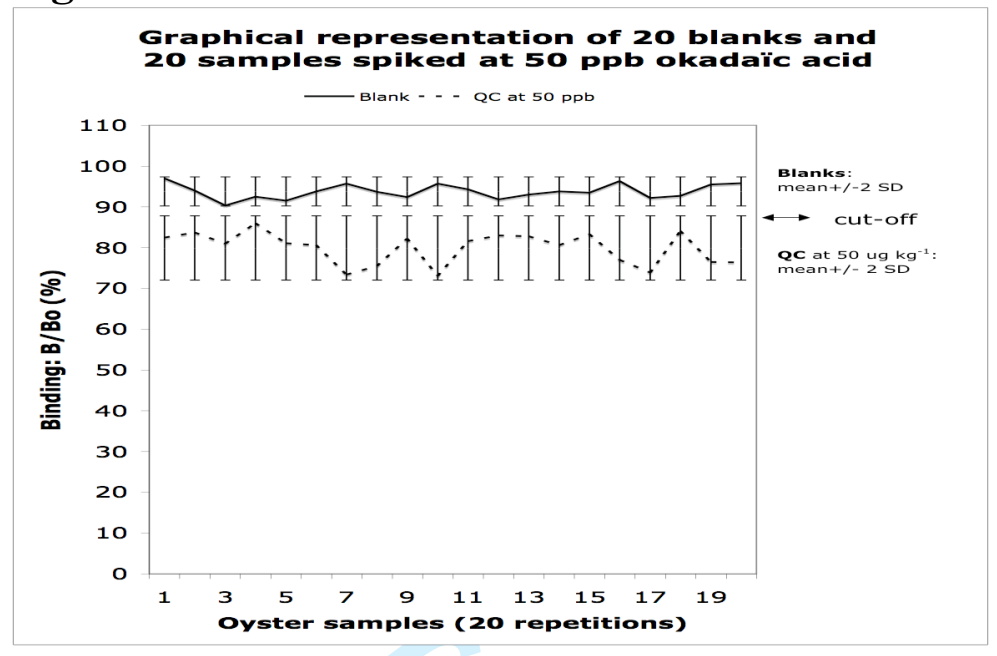




\section{Figure 4:}

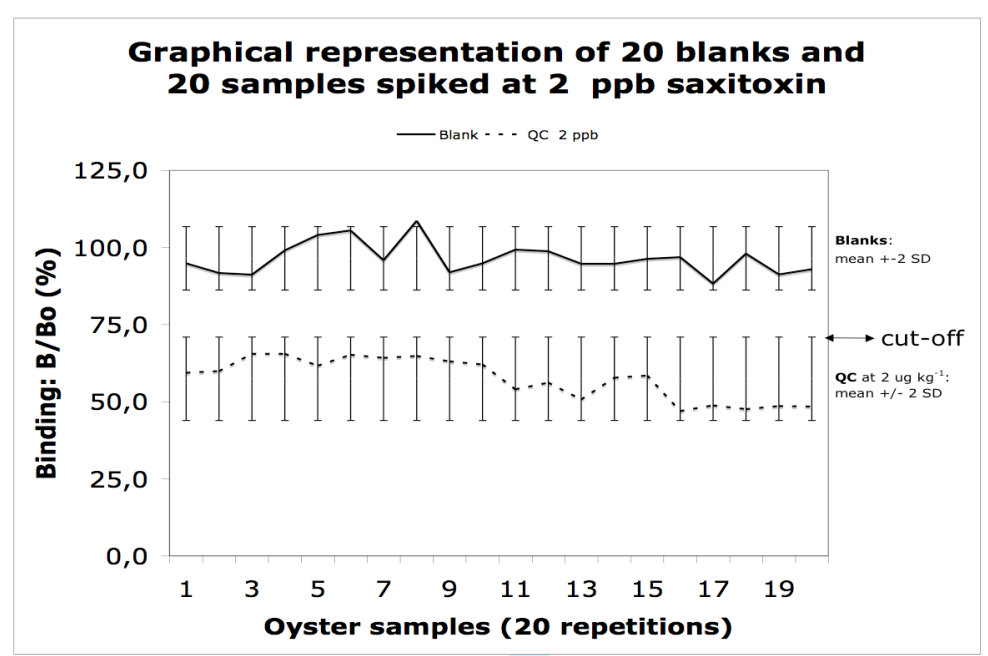

